University in 1933 and was awarded a Rhodes scholarship. $\mathrm{He}$ is a member of the American Philosophical Society, the Society of Experimental Psychologists, the Amcrican Psychological Association and the National Acadomy of Sciences. Dr. Pfaffmann is an anthority on the physiology and psychology of the senses of taste and smell and the bohaviour they control,

Prof. M. McCarty

DR. M. MoCarty has been appointed vice-president and professor of the Rockefeller Institute, where he will have primary responsibility for the development of clinical teaching and research and will suporvise all its hospital facilities. Dr. MeCarty graduated from Stanford University in 1933 and from the Johns Hopkins Medical School in 1937; he joinod the faculty of the Rockefoller Institute in 1941. Dr. MeCarty is a momber of tho Association of American Physicians, the Society for American Bacteriologists, the American Association of Tmmunolorists, and the National Acaderny of Soiences. Togother with Avery and MacLeod, he was a pioneer in demonstrating the bio. logical activity and genetic significance of deoxyribonucleio acid.

\section{Agricultural Research Council}

THw annual report for $1962-63$ of the Agricultural Research Council illustrates the continuing wide scope of both basic and applied scientific work carried out in the Council's Institutes and spocial Units (Pp. iv +91 . (Comud. 2519.) London: H.M. Stationery Offies, 1964. 6s. Bd. net). The appointment of Prof. S. R. Elsden as the first director of the new Food Research Institute at Norwich and the establishment of the Unit of Nitroger Fixation under the direction of Prof. J. Chatt at the University of Sussex are recorded. Developments of general interest are the monitoring of radioactivity in foodstuffs; the transmission of a plant virus by the zoospores of a soil fungus; improvements in electronmicrograph techniques for observing virus particles; and the radiometric assay of acetylcholinesternse, the enzyme which provides a chemical link between muscles and nerves in all living animals and which is inactivated by many insectieides. Important developments have been mado in the measurement of body temperature by the use of small radio transmitters fitted inside the body and in the screening of drugs, which on administration to the mother may be embryotoxic or teratogenic, by examining changes in the pro-implantation embryo. General accounts are given of work at four institutes, the Animal Breeding Research Organization, the National Institute for Research in Dairying, the Hannah Dairy Research Institute and the Welsh Plant Breeding Station. Summaries of the work of the two units administered by the Council are also included; these are the Unit of Embryology, nnder Prof. F. W. Rogers Brambell, and the Unit of Plant Physiology, directed by Prof. C. P. Whittinghim. The report eoncludes with appendixes of the committees of the Council exponditures, and spocial grants in support of research in universities.

The Society of Applied Pharmacological Sciences, Milan

A Society of Applied Pharmacological Sciences (Società di Scionze Farmacologiche Applicate) has beon established in Milan. The aim of the Society is to bring together, indopendontly of the orgarizations, institutes or laboratories where they aro employed, pharmacologists, microbiologists, biochemists, pathologists, and clinicnl resenreh workers concerned with research on now therapeutical agents. 'The Society intends to promote investi. gations and discussions of all thoso problems which concern the development of new drugs, and which, in their complexity, aro troated only partially by other scientific socicties dedicated mainly to basic research. Analysis and discussion of these problems by invostigators who are engaged in evaluating and realizing new drugs are of particular importance at a time when scientific and procedural criteria conceming the introduction of new compounds in thcrapy are being critically re-examined. The Society hopes to contribute through its activities, in co-operation with tho public hesalth organizations, to the grcater safety and efficiency of doveloping new drugs.

\section{International Filariasis Association}

IN order to promote the investigation and control of filariasis, an association was established, to be known as the International Filariasis Association (Société Internationalo des Filarioses). This grew out of earlier meetings held in 1955 and 1961, which were aimed at oxamining onchocerciasis under the auspices of the World Health Organization. 'The first general meeting of the Association was held at Rio do Janeiro on September 8, 1963, during the International Congresses of Tropical Medicine and Malaria, and the second at Rome on September 23, 1964, during the International Congress of Parasitology. Further general meotings will be hold when international con. gresses facilitate them. Steps will be taken, as and when possible, to promoto the investigation of all typos of filariasis through appropriate local meetings, and to provide an official channel for bringing the problems of filariasis to the notice of Govornments and international organizations. It is hoped to enlist the interest of all who are concerned with this subject. The officers of the Intornational Filariasis Association are as follows: President, Prof. J. F. Kessel (U.S.A.); Vice-Presidents, Prof. P. C. C. Garnham (U.K.) and Medical General P. Richet (France). There is un executive council of fifteen members representing the different regions of the world involved, and the secretaries are: Dr. M. Giaquinto (Italy) and Dr. F. Hawking, National Institute for Medical Research, London, N.W.7, from whom further information can be obtained.

\section{The Association of Commonwealth Universities}

The annual report of the Council of the Association of Commonwealth Universities for tho year ended July 31, 1964, records a membership of 139 institutions, of which 126 were miversities, 9 univorsity colleges and 4 approved institutions of higher education (Pp. 46. London: The Association of Commonwealth Universities, 1964). The work of the appointments department continued to incrense, and the Association assistod in filling some 1,294 vacancies compared with 1,146 in 1962-63. Ninety-one advisory committens were set up at the request of universities to interviow candidates in the United Kingdom; of appointmonts made by ovorsoas universities reported to the Association during the year, about 140 were of candidates who had applied from Britain in response to the Association's announcements, 95 being in Australia. Through its work for the Commonwealth Scholarship and Fellowship plun in the United Kingdom, the Association was eoncelned with the administration of the Marshall scholarships, the Frank Knox Mernorial fellowships, the Cornmonwonlth University Interchange. It also continued to assist the Drapers' Company in its scholarship scheme to enable British schoolboys to take first degrees in somo universities in Australia, Canada and New Zenland. The Association continued to act as the authority in the Unitod Kingdom to attest the eligibility for admis. sion to British universities of candidates seeking admission to French universities by virlue of examinations passed in Britain: 207 such attestations wore issued during the year. A briof account of the work of the comrnitten of Vice-chancellors and Principals of Univorsities of the United Kingdom is appended.

\section{National Museum of Canada}

Thw National Musoum of Canada Bulletin No. 202 (Anthropological Series No, 69) consists of a paper by 